\title{
INFLUENCE OF ACCESS TO PROGRAMME INFORMATION ON GENDER PARTICIPATION IN BASIC ADULT LITERACY DEVELOPMENT PROGRAMME IN NAKURU WEST SUB-COUNTY, NAKURU COUNTY, KENYA
}

\author{
Virginiah Kuria \\ Department of Development Studies, St. Paul's University, Limuru, Kenya \\ DOI: 10.46609/IJSSER.2021.v06i07.017 URL: https://doi.org/10.46609/IJSSER.2021.v06i07.017
}

\begin{abstract}
Basic adult literacy development programmes (BALDPs) are essential tools for developing communities. In Kenya, gender disparities have been observed in the programme enrolment, attendance, and completion rate. The present study sought to examine whether access to programme information has an influence on gender participation in BALDPs in Nakuru West Sub-County. The study employed the descriptive research design and targeted a population of 1,564 individuals consisting of 17 adult education instructors, as well as, 1,547 learners that were involved in adult literacy development programmes in Nakuru West Sub-County. The study sample was 16 instructors and 140 adult learners who were selected using the clustered random sampling technique. Semi-structured questionnaires were used to collect data from the learners while interview guides were used to gather data from instructors. Results showed that women had greater participation in the BALDP in Nakuru West than men in terms of enrolment, class attendance, class involvement, and course completion. The low participation of men in the programme was influenced significantly by their level of awareness of the content of BALDP ( $p$ $=0.032$ ) particularly the subjects that make up this programme. Based on these findings, the study recommends that the directorate of adult education should create awareness about the BALDP including its benefits, content and activities. Instructors should also orient all learners regarding the content of the programme at enrolment.
\end{abstract}

Keywords: Basic, Adult, Literacy, Programme, Information, Access, Nakuru

1. INTRODUCTION

1.1 Background of the Study 


\section{International Journal of Social Science and Economic Research}

ISSN: $2455-8834$

Volume:06, Issue:07 "July 2021"

Basic Adult literacy development programme (BALDP) is generally a course aimed at improving basic literacy skills such as reading, writing, numeracy, communication, and cultural literacy among grown persons (Pinder, 2011). Many societies have noted that lack of basic literacy skills leads to unemployment, underemployment and low political participation (Read Educational Trust, 2017). On the other hand, improved literacy contributes to economic growth, crime reduction, poverty reduction, increased civic engagement, improved health behaviours, cultural diversity, low birth rates and death rates, improved nutrition, increased self-esteem and empowerment. Improved literacy among adults also leads to increased mobility, better interaction with their children, changed attitudes towards domestic violence and more engagement in the social and political life of their communities (Chadha \& Wadhwa, 2018).

Basic Adult Literacy Development Programmes are a common phenomenon in many parts of the globe. In the United States of America (USA), Pinder (2011) found that millions of people join BALDPs but approximately $50 \%$ dropout before completing requirements or realizing the expected outcomes. In developing countries, BALDPs do not seem to achieve the primary objectives such as improved numeracy and reading skills and thus have received little attention or have been largely abandoned (Blunch, 2017). The modest performance of BALDPs in developing countries is attributed to low enrolment, high dropout rates and relapse into illiteracy. However, these programmes have been found to bring secondary benefits such as improved health, higher labour market participation and increased income. Major gender disparities have also been observed in the adult illiteracy trends. According to Lauglo (2010), adult women lag behind their male counterparts in terms of their level of schooling. Consequently, most BALDPs find it easy to attract female learners than males.

Artchison and Aldou (2009) also observed that most learners in BALDPs in Africa are women and the participation of men is declining. They noted that most BALDP in African nations give special access to women. Further, many African countries have programmes that specifically target women while some countries have placed their BALDP under ministries that deal with gender matters. Some countries have vocation training programmes and special livelihood programmes for women but none that target men. The accounts by Artchison and Aldou (2009) suggest that BALDPs programmes in Africa have been biased in favour of women. In most cases, the programmes are viewed as tools for promoting gender equality, which has led to the exclusion of women.

In Nigeria, Sanda (2014) found that more females were attending literacy classes compared to men. In her research done in Borno state in Nigeria, she found out that only $28 \%$ of the participants attending BALDP in 2011 were males. The author found that male participation in BALDP was hindered by dispositional barriers related to their thoughts and attitude, institutional barriers related to social norms and existing policies and situational barriers such as time and 


\section{International Journal of Social Science and Economic Research}

ISSN: $2455-8834$

Volume:06, Issue:07 "July 2021"

money. Stromquist (2016) noted that most illiterate men are not only poor but also find themselves in demanding situations of taking care of spouses and children. Therefore, these men get little time and opportunity to benefit from literacy classes and thus they remain illiterate.

Studies have shown gender differences BALDP participation could be attributed to gender differences in accessing information about these programmes. UNESCO (2010) found that Bolivian, Mexican and Nepalese women who had access to radio and other information sources were more likely to engage in adult education programmes. In recognition of the value of information, some of the countries have introduced career guidance centres that disseminate information regarding available literacy programmes, vocational education and training opportunities, continuing education and training and employment options. Other channels of communication have also been deployed including mass media, brochure and social media. In Philippines, UNESCO (2016) found that the sustainability of BALDP was enhanced through intensive campaigns and lobbying among communities that raised awareness regarding the importance of education and encouraged citizens to enrol in the programmes.

In their study, Ebner, Bendix, and Jager (2018) examined the strategies used in a sample of 21 European countries to create awareness for adult learning and education. The study established that awareness campaigns targeted three categories of audiences: the general public, special target groups such as senior citizens, and policy makers. The strategies that were used to create awareness among these groups include taking politicians and other policy makers on tours to adult learning centres, advertising on mass media to motivate the public to learn basic reading and writing skills, enlisting adult learners to act as mentors for new learners and taking citizens for educational walks. The study by Ebner et al. (2018) did not, however, show how these strategies influence gender disparity in access to information.

A major challenge that is often experienced when raising awareness for BALDP is that the target audience have low literacy levels (UNESCO, 2018). The illiteracy becomes a challenge as the message has to be translated into languages that the targets are familiar with and be conveyed through appropriate channels. Written channels may not be appropriate given that the targets have low reading skills. Online channels of communication such as social media may not also be appropriate given that people with low literacy may not have access to internet devices or have the requisite competence to use the devices. The relationship between literacy level and access to ICT was captured in a study by Chetty, Qigui, Gcora, Josie, Wenwei, and Fang (2018) where $24.2 \%$ of the respondents drawn from China cited educational constraints as their main barrier to internet use.

At independence, the Kenyan government identified ignorance as one of the major obstacles to the country's development. To promote literacy among its adult population who had not gotten 


\section{International Journal of Social Science and Economic Research}

ISSN: $2455-8834$

Volume:06, Issue:07 "July 2021"

the opportunity to attend school, the government established the Board of Adult Education (BAE) in 1966 under the Board of Adult Education Act (Republic of Kenya, 2012). The Act defines adult education as part-time or fulltime instructions of any kind provided to a person over the age of 16 years who is not in full-time attendance of primary, secondary or any college or university. The Act led to the creation of three forms of adult education programmes namely: literacy programmes, continuing education programmes and community education and extension programmes (Republic of Kenya, 2010). The aim of literacy programmes is to provide skills and knowledge to adults and youths who are out of school that enable them to improve their quality of life and their contribution to national development. The literacy programmes cover two main areas: basic literacy and post literacy programmes. The Basic Adult Literacy Development Programme (BALDP) is the focus of this study.

The BALDP seeks to equip illiterate adults and youths who are out of school with reading, numeracy, communication and writing skills. By 1979, the government had established 11,766 adult literacy centres with an enrolment of 415,074. The enrolment however started to drop and reached 93,052 by the year 2000 despite the fact that adult illiteracy level remained high. Apart from the low enrolment problem, Ndiku, Muthamia, Odeo, and Obaki (2009) noted that there were glaring gender and regional disparities in the provision of adult basic education. In 2005, female comprised the largest segment of learners in BALDP at $72.9 \%$ as compared to males whose proportion was $21.1 \%$ (Ndiku et al., 2009).

In another study, Mogeni (2012) found that $62.5 \%$ of individuals participating in BALDP in Masaba North Sub-County were women. A study by Wanja (2012) also found that $71 \%$ of the individuals enrolled in BALDP in Magumoni Sub-County in Meru County were women. These studies provide evidence regarding the existence of gender disparity in the Kenyan BALDP setup in favour of women. These studies did not, however, explore factors responsible for the gender disparity in the programme. The current study sought to address this gap by examining factors influencing gender participation in BALDP in Nakuru West Sub-County. In Nakuru County, it is estimated that $17 \%$ of adults have no formal education while the rate of illiteracy among males stands at 16.2\% (Kenya National Bureau of Statistics, 2013).

The gender disparity in BALDP in favour of women suggests that these men may not get the opportunity to benefit from the programme. The disparity also goes against the BAE policy of equity, which asserts the need to accord equal opportunities in the distribution of programmes, resources and services. It is not clear what factors have contributed to the gender differences in BALDP participation in Kenya. It is in this regard that this study sought to examine the influence of access to programme information on gender participation in adult literacy development programme in Nakuru West Sub-County. 
International Journal of Social Science and Economic Research

ISSN: 2455-8834

Volume:06, Issue:07 "July 2021"

\section{RESEARCH METHODOLOGY}

\subsection{Research Design, Study Site, and Target Population}

This study made use of the descriptive research design. The study was Nakuru West SubCounty; one of the 11 sub-counties that make up Nakuru County in Kenya. According to the County Government of Nakuru (2018), the sub-county has an estimated human population of 213,702. It is divided into six administrative wards namely: Barut, London, Kaptembwa, Kapkures, Rhonda and Shabab. Nakuru West has a total of 11 adult literacy centres.

The target population was 1,564 individuals comprising of 17 adult education instructors stationed in Nakuru West Sub-County, as well as, 1,547 adult learners who enrolled in the BALDP in Nakuru West Sub-County (Nakuru West Sub-County Adult and Continuing Education Officer, 2018). These individuals were targeted because they had direct experience with the BALDP in the study area and thus, they were in the best position to provide information regarding factors that influence gender participation.

\subsection{Sample Size Determination and Sampling Technique}

A sample was selected from the target population for purposes of data collection. The sample size for the study was determined using the Mugenda and Mugenda (2003) recommendation that for a large population of above 1,000 individuals, a sample that is equivalent to $10 \%$ of the population would be sufficient for statistical analysis. Based on this recommendation, the appropriate sample size for the study was determined as 156 individuals.

Random sampling technique was used to select respondents from the population. First, ten centres were selected from the 11 adult learning centres that were in existence in Nakuru West Sub-County using the lottery method. The names of the 11 centres were written on small pieces of papers, folded and shuffled. The researcher then picked 10 pieces of papers and the names of the centres contained therein were included in the study. The remaining centre was left out for purposes of conducting the pilot study. The 10 centres that were selected using the lottery method had 16 instructors who were automatically included in the study. In addition, 14 learners were selected randomly from each of the 10 centres to make a total of 140 learners.

\subsection{Data Collection Tools}

Two instruments of data collection were used: (1) questionnaire for adult learners included in this document as Appendix I, and (2) interview guide for instructors. The questionnaire was developed in line with the study variables that included gender participation in BALDP and access to programme information. These variables were measured using various statements that 
International Journal of Social Science and Economic Research

ISSN: 2455-8834

Volume:06, Issue:07 "July 2021"

respondents were asked to rate on a five-point scale. It also comprised a section that collected the demographic information of the respondents.

An interview guide was used to collect data from instructors in the adult literacy centres in Nakuru West Sub-County. The guide was semi-structured in nature, meaning that it comprised a list of uniform initial questions that were posted to all participants, and follow-up questions that differed from one interviewee to the next based on their responses to the initial questions. The guide was also divided into three sections with the first section focusing on respondents' demographic information and the remaining two contain questions that relate to the variables of the study.

\subsection{Piloting of Research Tools}

Both the questionnaire and the interview guide were pilot-tested by collecting data from Nakuru District Headquarter A. centre. The pilot study involved 14 individuals consisting of 1adult education instructor and 13 adult learners. The sample size for the pilot study was equivalent to $10 \%$ of the sample size for the main study. The centre was not included in the data collection for the main study.

The pilot study data was used to enhance the validity of the research instrument. The pilot study data revealed that most of the items in the data collection instrument elicited the information needed to address the research questions. A few questions were restructured because they were left unanswered by a several respondents suggesting that they might have been too technical. Validity was further enhanced by subdividing the instruments into sections that cover each study variable so as to ensure that all variables are adequately covered. Content and construct validity was established by subjecting the research instrument to scrutiny by university supervisors and other faculty staff (Bryman, 2016).

The pilot study data also helped to assess the reliability of the questionnaire. The Cronbach alpha method was used to test reliability. This method gave each scale an alpha that ranges between 0 and 1 (Mohajan, 2017). Table 1 presents the results of the reliability analysis.

Table 1: Cronbach Reliability Test Results

\begin{tabular}{lcc}
\hline Variable & No. of Items & Cronbach alpha \\
\hline Gender participation in BALDP & 14 & 0.812 \\
Access to programme information & 11 & 0.789 \\
\hline
\end{tabular}

Source: Pilot Data (2020) 
International Journal of Social Science and Economic Research

ISSN: 2455-8834

Volume:06, Issue:07 "July 2021"

Results in Table 1 show that the scales for two variables of the study had Cronbach alpha that were greater than 0.7. The scales were thus deemed to have acceptable levels of reliability. All the analysis was conducted using the Statistical Packages for Social Science (SPSS) version 25 data analysis software.

\subsection{Field Work}

Research approval was obtained from St. Paul's University, the National Commission for Science, Technology and Innovation (NACOSTI), the Nakuru County Commissioner and the Nakuru County Director of Education. Once these approvals were obtained, the researcher approached the heads of the learning centres, explained the study to them and asked for permission to conduct the research in their centres. The centres include Probation Girls, Blessings Learning Centre, Filadelphia Women Crisis Centre, St. Francis Adult Basic Centre, GK Nakuru Women Prison, GK Nakuru Men Prison, Love for All Centre, Ingobor Centre, London centre, and the Nakuru District Headquarter B. centre. The researcher with the assistance of the instructors selected adult learners in each centre, informed them about the study and personally administered the questionnaire to those who agreed to participate. The questionnaire was administered by the researcher rather than being left to the respondents in order to overcome the illiteracy barrier. All the instructors present in the 11 adult literacy centres were also interviewed.

\subsection{Data Analysis Methods}

Quantitative data was sorted, coded and entered into the SPSS version 25 soft ware where it was analysed using both descriptive and inferential statistics. Descriptive statistics such as percentages, frequencies and means were used to describe the current situation within the literacy programmes in relations to the study variables. Inferential statistics were used to examine the significance of the relationship between the independent and dependent variables. The specific inferential statistic that was used in this study was chi-square, which was interpreted at 0.05 level of significance. The results were presented using Tables.

Qualitative data was analysed using the thematic analysis technique. This method entailed analysing responses from all interviewees, identifying similarities and differences in responses, and creating themes that relate to gender participation in BALDP, socio-cultural factors, household economic factors, and access to information about BALDP (Maguire \& Delahunt, 2017). Qualitative findings were presented using quotations and discussions.

\section{DATA ANALYSIS, PRESENTATION AND INTERPRETATION}

\subsection{Response Rate}


International Journal of Social Science and Economic Research

ISSN: 2455-8834

Volume:06, Issue:07 "July 2021"

Out of the 156 individuals who were expected to participate, 146 responded by either completing a questionnaire or participating in an interview. This figure translates to a response rate of 93.6\%. According to Fincham (2018), a response rate of $60 \%$ or above is usually the expectation of most journal editors while for surveys envisioned to represent a large population, a response rate of $80 \%$ is expected. The response rate for the present study certainly meets these expectations.

Table 2: Response Rate

\begin{tabular}{lccc}
\hline Category & Expected No. & Actual No. & Response Rate \\
\hline Adult learners & 140 & 131 & $93.6 \%$ \\
Instructors & 16 & 15 & $93.8 \%$ \\
Total & $\mathbf{1 5 6}$ & $\mathbf{1 4 6}$ & $\mathbf{9 3 . 6 \%}$ \\
\hline
\end{tabular}

Source: Field Data (2020)

Table 2 presents a breakdown of the response rate for the two categories of respondents (adult learners and instructors). The response rate for adult learners was $93.6 \%$ as 131 out of the expected 140 learners duly completed their questionnaires. The response rate for instructors was $93.8 \%$ as one instructor was not available for the interview.

\subsection{Respondents Demographic Profile}

The gender of respondents was assessed in terms of whether the respondent was male or female. Results showed that there were more female adult learners $(59.5 \%)$ than males $(40.5 \%)$ in the study sample. The results highlight that there is a gender disparity in the BALDP in Nakuru West in favour of women. The studies by Mogeni (2012) and Wanja (2012) also found that men were underrepresented in BALDP in Masaba North Sub-County and Magumoni Sub-County in Meru County respectively. Current findings coupled with the results of these studies suggest that the BALDP in Kenya may not be gender sensitive. They suggest that there might be elements in the BALDPs that contribute to low enrolment and retention of men in the programmes.

The majority of the learners $(58.8 \%)$ were in the $20-40$ years' age brackets. About $26.7 \%$ were below 20 years and 12.2\% were between 41 and 60 years. Only $2.3 \%$ were above the age of 60 years. These findings denote that majority of the learners in BALDP centres in Nakuru West Sub-County are in the early and middle adulthood age. However, the programme has attracted individuals of different age groups including those who are past 60 years. The youthful learners are probably those who had dropped out of formal schooling in their childhood and had decided to advance their education. Ndegwa (2016) advanced that the middle aged learners mainly desire 


\section{International Journal of Social Science and Economic Research}

ISSN: $2455-8834$

Volume:06, Issue:07 "July 2021"

to add some skills or their circumstances necessitates that they acquire basic adult literacy. The elderly learners are largely motivated by the need for self-actualization and to improve their selfesteem. The age disparity among the learners could be responsible for gender disparities in the BALDP as intergenerational differences may make some learners feel out of place within the programme. The effect may apply differently for male and female. Lauglo (2010) also noted that BALDP targets persons who are deemed to be too old to attend regular primary schools and who missed primary education to the extent that they failed to acquire basic literacy skills. The age range targeted by the BALDP is quite wide and thus each institution offering BALDP should tailor its content to the specific age of the learners. If a centre attracts future adults who are not motivated by the need to acquire credentials, the centre should provide content that directly affects their life.

The majority of the instructors (66.7\%) were in 20-40 age brackets while the remaining $33.3 \%$ were between 40 and 60 years. These results also imply that the instructors were in the early and middle adulthood age, which is the same age as majority of the learners. The similarity in the ages of the majority of learners and instructors could have both a positive and negative implication on gender participation in BALDP. On one hand, the age similarity may make it easier for the instructors and learners to interact. On the other hand, the age similarities may affect the self-esteem of some learners who may feel embarrassed of receiving instruction from peers. The self-esteem issue may affect male and female learners differently. No instructor was below the age of 20 years or above 60 years, which is in line with government policy that set the retirement age for teachers in the BALDP at 60 years (Ndegwa, 2016).

About $32.8 \%$ were married, $4.6 \%$ were divorced or separated, and $3.8 \%$ were widows or widowers. The proportion of married learners in this programme is much lower than that recorded in the study by Wanja (2012), who found that $81.3 \%$ of learners in BALDP centres in Meru South Sub-County were married. This discrepancy suggests that there might be substantial diversity in the learners attending BALDP in different parts of the country in terms of demographic variables such as marital status. Consequently, contextual factors should be considered when interpreting findings of studies investigating adult literacy programmes.

\subsection{Gender Participation in BALDP}

The dependent variable of the study was gender participation in BALDP. The study sought to determine the extent to which both males and females participated in the programme. One of the indicators that were used to measure this variable was enrolment to the BALDP by males and females. Learners were presented with two questions related to enrolment and asked to indicate their level of agreement with each on a five point scale (1=strongly disagree, $2=$ disagree, $3=$ undecided, 4=agree, and 5=strongly agree). The strongly disagree and disagree responses were 
International Journal of Social Science and Economic Research

ISSN: 2455-8834

Volume:06, Issue:07 "July 2021"

combined since they both indicated that the respondents had negated the statement while agree and strongly agree responses were also combined. Results are presented in Table 3.

\section{Table 3: Enrolment of Males and Females in BALDP}

\begin{tabular}{|c|c|c|c|c|c|}
\hline \multicolumn{6}{|c|}{ Key: $1=$ strongly disagree, $2=$ disagree, $3=$ undecided, $4=$ agree, and $5=$ strongly agree } \\
\hline Statement & $\begin{array}{c}1 \\
(\%)\end{array}$ & $\begin{array}{c}2 \\
(\%)\end{array}$ & $\begin{array}{c}3 \\
(\%)\end{array}$ & $\begin{array}{c}4 \\
(\%)\end{array}$ & $\begin{array}{c}5 \\
(\%)\end{array}$ \\
\hline $\begin{array}{l}\text { In our class, the number of male and female students is more or less } \\
\text { the same }\end{array}$ & 28.2 & 8.4 & 2.3 & 32.8 & 28.2 \\
\hline Many female students have joined the course & 9.9 & 12.2 & 5.3 & 29.0 & 43.5 \\
\hline Many male students have joined the programme & 22.9 & 22.9 & 7.6 & 29.8 & 16.8 \\
\hline
\end{tabular}

Source: Field Data (2020)

Three scenarios were examined; (1) rate of male and female enrolment being more less the same, (2) there being more female enrolling to a centre, and (3) there being more male learners joining the programme. Results in Table 4.3 shows that the $29.0 \%$ of the respondents agreed and another $43.5 \%$ strongly agreed with the position that there were many female students joining the BALDP in their centres. About $61.0 \%$ agreed or strongly agreed that the number of male students is more or less the same while only $46.6 \%$ agreed or strongly agreed that many male students were joining the programme. These results suggest that there is higher enrolment of females in the BALDP in Nakuru West Sub-County. They also demonstrate apathy and disinterest among the males towards the BALDP.

The results are reinforced by qualitative data where most of the instructors who were interviewed affirmed that the number of female learners was higher than the male learners in their classes (Interview Data, 2020). Similar findings were also observed in the study by Mogeni (2012), who found that enrolment and attendance was higher among men than women in Masaba North SubCounty BALDP centres. Wanja (2012) also found that more females than males were enrolling in BALDP in Magumoni Sub-Counties respectively. These findings suggest that males have not fully embraced the BALDP across the country. They also suggest that there are elements within the programme and the communities that hinder the full participation of males in the programme. The present study sought to uncover these factors.

Class attendance by male and female learners was used as another indicator to asses gender participation in BALDP. Respondents were asked to give their views on several issues related to class attendance. Results are summarized in Table 4. 
International Journal of Social Science and Economic Research

ISSN: 2455-8834

Volume:06, Issue:07 "July 2021"

Table 4: Class Attendance by Male and Female Learners

\begin{tabular}{|c|c|c|c|c|c|}
\hline \multicolumn{6}{|c|}{ Key: $1=$ strongly disagree, $2=$ disagree, $3=$ undecided, $4=$ agree, and $5=$ strongly agree } \\
\hline Statement & $\begin{array}{c}1 \\
(\%)\end{array}$ & $\begin{array}{c}2 \\
(\%)\end{array}$ & $\begin{array}{c}3 \\
(\%)\end{array}$ & $\begin{array}{c}4 \\
(\%)\end{array}$ & $\begin{array}{c}5 \\
(\%)\end{array}$ \\
\hline $\begin{array}{l}\text { The class attendance of male and female students at this centre is } \\
\text { more or less the same }\end{array}$ & 25.2 & 27.5 & 1.5 & 22.9 & 22.9 \\
\hline Male students attend most of the classes consistently & 18.3 & 22.9 & 6.9 & 28.2 & 23.7 \\
\hline Female students attend most of the classes consistently & 13.0 & 11.5 & 4.6 & 29.8 & 41.2 \\
\hline Most male students arrive to class before the lessons begin & 16.8 & 18.3 & 7.6 & 26.7 & 30.5 \\
\hline Most female students arrive to class before the lessons begin & 7.6 & 12.2 & 11.5 & 28.2 & 40.5 \\
\hline
\end{tabular}

Source: Field Data (2020)

Results in Table 4 illustrate that majority of the respondents either strongly disagreed (25.2\%) or disagreed $(27.5 \%)$ with the assertion that class attendance of male and female students at their centre was more or less the same. About $51.9 \%$ of the respondents held the view that male students attend most of the classes consistently as opposed to $71 \%$ who felt that female students attended classes consistently. In terms of class arrival time, more respondents $(68.7 \%)$ said that female students arrive to class before the lesson begins than those who reported that male students arrive to class on time (57.3\%). These results suggest that female learners have better class attendance when compared to male learners. Poor class attendance among the males limits them from benefiting from adult literacy development programme. Poor class attendance sets men up to remain behind in fundamental skills that they require in order to learn more complicated stuff. When they finally attend classes, they find it difficult to catch up with the rest of the learners. Chronic absenteeism could also roll-back the gain that men get from BALDP causing them to relapse into illiteracy.

Current findings are consistent with the study by Wanja (2012) who found that $30 \%$ of male students enrolled in the BALDP in Magumoni Sub-County attended at least 5 lessons per week as compared to $42.8 \%$ of female learners. Missing 5 lesson per week falls under the definition of chronic absenteeism. The findings by Wanja (2012) indicated that chronic absenteeism among males is a widespread phenomenon in the country BALDP set up. The findings are also supported by the qualitative data gathered during interviews with the instructors. Most of the interviewees affirmed that the attendance of female students was quite good and that most were always available for class. Some also reported that female learners were more punctual than males. A few interviewees, however, gave differing views suggesting that gender difference in class attendance varies from one learning centre to the next. 
International Journal of Social Science and Economic Research

ISSN: 2455-8834

Volume:06, Issue:07 "July 2021"

The third indicator that was used to measure gender participation in BALDP is the involvement in class by male and female learners. Respondents were asked to give their views on several statements relating to this issue. Their views are summarised in Table 5.

Table 5: Class Involvement by Male and Female Learners

\begin{tabular}{|c|c|c|c|c|c|}
\hline Statement & $\begin{array}{c}1 \\
(\%)\end{array}$ & $\begin{array}{c}2 \\
(\%)\end{array}$ & $\begin{array}{c}3 \\
(\%)\end{array}$ & $\begin{array}{c}4 \\
(\%)\end{array}$ & $\begin{array}{l}5 \\
(\%)\end{array}$ \\
\hline $\begin{array}{l}\text { There is active involvement of both male female students in class } \\
\text { activities including answering questions }\end{array}$ & 9.9 & 3.8 & 5.3 & 29.0 & 51.9 \\
\hline $\begin{array}{l}\text { Most male students usually complete all their assignments as } \\
\text { instructed by the teacher }\end{array}$ & 9.2 & 13.7 & 9.9 & 18.3 & 48.9 \\
\hline $\begin{array}{l}\text { Most female students usually complete all their assignments as } \\
\text { instructed by the teacher }\end{array}$ & 8.4 & 3.1 & 13.0 & 28.2 & 47.3 \\
\hline
\end{tabular}

Source: Field Data (2020)

Results in Table 5 show that majority of the respondents either agreed (29\%) or strongly agreed $(51.9 \%)$ that there is active involvement in class activities by both male and female learners. More respondents $(75.5 \%)$ agreed that most female learners usually complete all their assignments as instructed by the teacher as compared to those who felt that male students also complete their assignment (67.2\%). These findings imply that there is active involvement in classroom activities by learners of different gender but the level of involvement particularly when it comes to completion of assignment is higher among female learners. They show that female learners are more motivated than males to engage in classroom activities and are more committed to the learning process marked by completion of assignments given by teachers.

Class involvement has a major bearing on the quality of learning as well as on learning outcomes. The low involvement by male learners in BALDP is therefore a point of concern. The qualitative data also point to the fact that there is low class involvement by male learners in the BALDP. Most of the interviewed instructors indicated that female learners were more active in responding to questions in class, asking questions, engaging in discussions with fellow learners and completing their assignments. One instructor explained that:

Female are involved in class activities more than male because they are influenced by the others and they want to improve their knowledge. (Instructor3, Female, 2020). 
International Journal of Social Science and Economic Research

ISSN: 2455-8834

Volume:06, Issue:07 "July 2021"

Gender differences in class involvement can be attributed to a multitude of factors including the structure of classroom, teaching strategy deployed by the instructor and learning motivation. The current study focused on the role played by socio-cultural factors, household economic factors and access to information in determining class involvement by male and female students. The final indicator that the study used to gauge gender participation in BALDP is programme completion rates of male and female learners. Respondents were given a set of statement relating to this issue and asked to give their views. Results are summarized in Table 6.

Table 6: Course Completion by Male and Female Learners

\begin{tabular}{lccccc}
\hline Key: $1=$ strongly disagree, $2=$ disagree, $3=$ undecided, 4= agree, and 5 = strongly agree & & & \\
\hline Statement & $\mathbf{1}$ & $\mathbf{2}$ & $\mathbf{3}$ & $\mathbf{4}$ & $\mathbf{5}$ \\
$(\mathbf{\%})$ & $(\boldsymbol{\%})$ & $(\boldsymbol{\%})$ & $\begin{array}{c}(\boldsymbol{\%}) \\
(\boldsymbol{\%})\end{array}$ \\
\hline $\begin{array}{l}\text { The number of male and female students who complete the course in } \\
\text { the centre is more or less the same }\end{array}$ & 14.5 & 12.2 & 7.6 & 38.9 & 26.7 \\
$\begin{array}{l}\text { Many male students complete their course in this centre } \\
\text { Many female students complete their course in this centre }\end{array}$ & 13.7 & 13.0 & 8.4 & 38.9 & 26.0 \\
& 6.1 & 3.8 & 13.0 & 34.4 & 42.7 \\
\hline
\end{tabular}

Source: Field Data (2020)

Results in Table 6 shows that $65.6 \%$ of the respondents either agreed (38.9\%) or strongly agreed (26.7\%) that the number of male and female students who complete the course in their respective centres is more or less the same. About $64.9 \%$ reported that many male students complete their course while $77.1 \%$ said that many female students complete their course. These results suggest that the completion rate of female learners is higher than that of males as the percentages of respondents who reported that many female students complete their course is higher than those who said that many male students complete their course. These findings are consistent with the study by UNESCO (2017), who found that in Europe, women who were active in the labour force were more likely to participate and complete education and training programmes when compared to males. UNESCO (2017) also found that majority of the individuals graduating from institutions of higher learning across the globe were women. The findings, however, relate to higher education rather than basic adult education, which is the focus of the present study.

\subsection{Access to Programme Information influence on Gender Participation in BALDP}

The objective of the study was to examine the influence of access to programme information on gender participation in BALDP. The study examined the influence of access to three types of information namely information on BALDP existence, information on benefits of BALDP and information on content of the BALDP. 
International Journal of Social Science and Economic Research

ISSN: 2455-8834

Volume:06, Issue:07 "July 2021"

\subsubsection{Influence of Information on Programme Existence on Gender Participation in BALDP}

According to Windisch (2015), people with lower education attainment tend to exhibit lower tendency to seek information about learning opportunities. In England, it was found that few low-literacy adults knew the government provided free training for mathematics and English. The current study sought to establish whether males and females in Nakuru West have differential access to information regarding the existence of BALDP leading to gender disparities in BALDP participation. To assess this issue, respondents were first required to indicate where they learnt about the BALDP. Their responses are summarised in Table 7.

Table 7: Source of Information on BALDP

\begin{tabular}{lcc}
\hline Source of Information & Male (\%) & Female (\%) \\
\hline Friends/ Family Members & 90.6 & 82.1 \\
Mass media & 1.9 & 5.1 \\
Social media & 3.8 & 12.8 \\
Institution & 3.8 & 0.0 \\
\hline
\end{tabular}

Chi-Square 6.899, $\mathrm{df}=3, \mathrm{p}=.075$

Source: Field Data (2020)

Table 7 illustrates that $90.6 \%$ of male respondents and $82.1 \%$ of females said that they got to know about the BALDP from friends or family members. These findings imply that word of mouth is the most popular channel through which community members' access information regarding BALDP. This means that the programme is largely dependent on those who have gone through it to pass information to other people who may not know about the programme's existence. Therefore, the experience of learners in the BALDP programme is a major determinant of the extent to which information regarding the existence of the programme will be spread to other members of the community. Learners who get poor experiences in the BALDP cannot sell the programme to others.

The chi-square test showed that there was no statistically significant difference in how male and female learners got information about BALDP $(\mathrm{p}=0.075)$. This implies that both male and female learners had similar source of information, which for most learners was family and friends. These findings implies that sources of information regarding BALDP existence cannot explain the gender differences in BALDP participation as both male and female learners have similar sources of information. Access to information on BALDP was further interrogated by asking 
International Journal of Social Science and Economic Research

ISSN: 2455-8834

Volume:06, Issue:07 "July 2021"

respondents to give their views on three statements relating to this subject. Their responses are summarized in Table 8.

Table 8: Access to Information on BALDP Existence by Males and Females

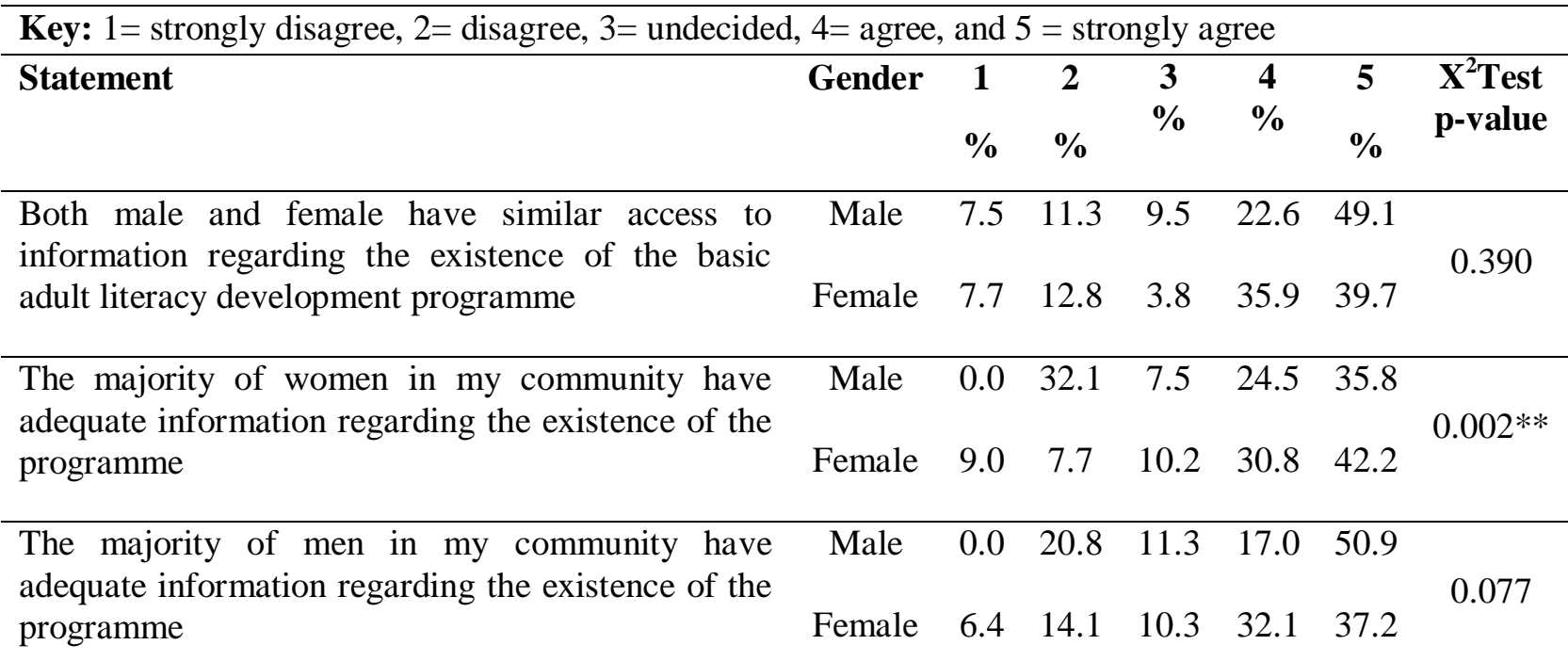

\footnotetext{
**Significant at the 0.01 level

Source: Field Data (2020)
}

Results in Table 8 indicate that majority of the respondents held the view that men and women within their communities have similar access to information regarding BALDP existence. This position was more popular among the female respondents $(75.6 \%)$ than male respondents (71.7\%), but the chi-square test shows that this difference is not statistically significant $(\mathrm{p}=0.390)$. Most of the respondents also believed that majority of the men and women in their communities have access to information regarding BALDP existence. These findings are not consistent with the study by Kenyan National Bureau of Statistics (2007), which found that only $31 \%$ of Kenyan adults were aware of the existence of BALDP. The inconsistency may be explained by the 13-years' time difference between the Kenyan National Bureau of Statistics study and the current study. Proliferation of information regarding BALDP may have increased during this period.

The proportion of female respondents who believe that women in their community had access to information on BALPD existences $(73.1 \%$ ) was significantly higher than that of male respondents who shared similar views (60.3\%). These findings imply that male and female respondents had different perspectives regarding access to information on BALDP existences among the womenfolk in their communities. Nonetheless, at $60.3 \%$, majority of the male 
International Journal of Social Science and Economic Research

ISSN: 2455-8834

Volume:06, Issue:07 "July 2021"

respondents also held the view that women in the community had access to this information. These findings reinforce the position arrived at earlier that access to information on BALDP existence cannot explain gender disparities in BALDP participation because male and female have similar access to information. These findings are also not congruent with the study by Kenya National Bureau of Statistics (2007), who found that the level of awareness of BALDP existence was higher among males $(32.1 \%)$ as compared to $26 \%$ for females. This inconsistency can also be explained by the time difference between the two studies.

\subsubsection{Information on Programme Benefits influence on Gender Participation in BALDP}

The study also sought to determine whether males and female have differential access to information regarding the benefits of BALDP, which could explain gender disparities in programme participation. To assess this issue, respondents were first requested to indicate the primary reason that motivated them to join the programme. Their responses are summarized in Table 9.

Table 9: Reason for Joining the BALDP

\begin{tabular}{lcc}
\hline Reasons & Male (\%) & Female (\%) \\
\hline To get a job & 7.5 & 9.0 \\
To become more effective in my current & 15.1 & 10.3 \\
job & 66.0 & 50.0 \\
To increase my understanding of life issues & 11.3 & 30.8 \\
To improve my status in the community &
\end{tabular}

Chi-Square 7.330, $\mathrm{df}=3$, p=.062

Source: Field Data (2020)

Table 9 shows that majority of the respondents joined BALDP with the primary aim of increasing their understanding of life. More males (66\%) than females $(50 \%)$ cited this as the primary reason for joining BALDP. The second frequently mentioned reason for joining B ALDP by men was to become more effective in current job (15.1\%), the third was to improve status in the community $(11.3 \%)$ while the last reason was to get a job (7.5\%). Among the female respondent, the second most commonly cited reason for joining BALDP was to improve status in the community $(30.8 \%)$, the third was to become more effective in current job $(10.3 \%)$ and the last is to get a job (9\%).

The findings imply that there are slight differences in the reason that motivated males and females to join the programme. This is consistent with Lauglo (2010) who argued that the gender of BALDP target group has an impact on the contents of the programme. However, the chi- 
International Journal of Social Science and Economic Research

ISSN: 2455-8834

Volume:06, Issue:07 "July 2021"

square test showed that male learners' responses did not differ significantly from female learners' responses on this issue $(p=0.062)$. This means that the difference between the motivation of males and female learners was negligible and thus cannot explain the disparity in gender participation in BALDP in Nakuru West Sub-County. To further assess this issue, respondents were asked to indicate the primary benefit that they expect to gain from the BALDP. Their responses are summarised in Table 10.

Table 10: Benefits that Respondents Anticipate from BALDP

\begin{tabular}{lcc}
\hline Benefits & Male (\%) & Female (\%) \\
\hline Career advancement & 15.1 & 20.5 \\
Realization of full potential & 24.5 & 37.2 \\
Improved self-esteem & 32.1 & 39.7 \\
Networking & 28.3 & 2.6 \\
\hline
\end{tabular}

Chi-Square 18.696, $\mathrm{df}=3, \mathrm{p}=.000$

Source: Field Data (2020)

Results in Table 10 show that there is a difference between the benefits anticipated by male and female learners. Among male learners, the most frequently mentioned benefit was improved selfesteem $(32.1 \%)$ followed by networking $(28.3 \%)$, and then realization of full potential $(24.5 \%)$ and finally career advancement $(15.1 \%)$. The most commonly mention benefit by female learners was improved self-esteem $(39.7 \%)$ followed by realization of full potential $(37.2 \%)$, career advancement $(20.5 \%)$ and lastly networking $(2.6 \%)$. The chi-square test shows that the difference in the benefits anticipated by males and females was statistically significant $(\mathrm{p}=0.000)$. This implies that what male learners anticipate to gain from the BALDP programme is different from what female learners anticipate to gain.

This difference may explain the gender disparity in BALDP participation. Since the earlier data shows that BALDP participation is lower among men, these findings suggest that the BALDP in Nakuru West falls short of delivering the benefits anticipated by male learners leading to fewer enrolment, low class attendance and low completion rate. These findings are consistent with the study by Korpershoek and King (2019) who found that male students in American higher education setup were more extrinsically motivated than female learners. This implies that the males' interest in learning was largely driven by the need to attain tangible rewards such as better jobs, salary increment and business opportunity. 
International Journal of Social Science and Economic Research

ISSN: 2455-8834

Volume:06, Issue:07 "July 2021"

This trend is also visible in the Nakuru West BALDP setup where networking was the second most frequently identified benefits by male workers. Networking tends to provide extrinsic rewards such as business opportunities and career advancement and thus current findings implies that male learners in the BALDP centres in Nakuru West are more extrinsically motivated than female learners. The findings also question the capacity of the programme to deliver the extrinsic rewards anticipated by male learners leading to low participations by males. To further assess the access to information on BALDP benefits, respondents were given a list of statements and asked to give their views on each. Their responses are presented in Table 11.

Table 11: Influence of Access to Information on Benefits of BALDP by Males and Females

\begin{tabular}{|c|c|c|c|c|c|c|c|}
\hline \multicolumn{8}{|c|}{ Key: $1=$ strongly disagree, $2=$ disagree, $3=$ undecided, $4=$ agree, and $5=$ strongly agree } \\
\hline \multirow[t]{2}{*}{ Statement } & \multirow[t]{2}{*}{ Gender } & 1 & 2 & 3 & 4 & 5 & \multirow{2}{*}{$\begin{array}{l}\mathbf{X}^{2} \text { Test } p- \\
\text { value }\end{array}$} \\
\hline & & $\%$ & $\%$ & $\%$ & $\%$ & $\%$ & \\
\hline \multirow{2}{*}{$\begin{array}{l}\text { I understand the benefits of the basic literacy } \\
\text { development programme }\end{array}$} & Male & 3.8 & 0.0 & 9.4 & 32.1 & 54.7 & \multirow{2}{*}{0.177} \\
\hline & Female & 2.6 & 2.6 & 2.6 & 46.2 & 46.2 & \\
\hline \multirow{2}{*}{$\begin{array}{l}\text { Women in my community understand the } \\
\text { benefits of this programme }\end{array}$} & Male & 1.9 & 9.4 & 24.5 & 24.5 & 39.6 & \multirow{2}{*}{0.236} \\
\hline & Female & 5.1 & 14.1 & 11.5 & 33.3 & 35.9 & \\
\hline \multirow{2}{*}{$\begin{array}{l}\text { Men in my community understand the benefits } \\
\text { of this programme }\end{array}$} & Male & 3.8 & 5.7 & 9.4 & 30.2 & 50.9 & \multirow{2}{*}{0.327} \\
\hline & Female & 3.8 & 16.7 & 9.0 & 33.3 & 37.2 & \\
\hline
\end{tabular}

Source: Field Data (2020)

Results in Table 11 show that majority of male learners (86.8\%) and female learners (92.4\%) understand the benefits of BALDP. The chi-square test showed that there is no statistically significant difference between the number of male learners and female learners who understand these benefits $(\mathrm{p}=0.177)$. Similarly, majority of the male respondents $(64.1 \%)$ and female respondents $(68.9 \%)$ said that women in their communities understand the benefits of the programme. Further, majority of the male respondents $(81.1 \%)$ and female respondents $(70.5 \%)$ held that men in the communities understand the benefits of the BALDP. These findings imply that the understanding BALDP's benefits high not only among men and women who are enrolled in the programme but also those who are in the community including those who have not enrolled. The findings thus imply that access to information on BALDP benefits cannot explain the disparity in BALDP participation by men and women. Earlier findings rather show that it is not access to information about these benefits that shapes gender participation in BALDP but 
International Journal of Social Science and Economic Research

ISSN: 2455-8834

Volume:06, Issue:07 "July 2021"

rather men's and women's priorities regarding the benefits that they would like to gain and their perception regarding the capacity of the programme to deliver the anticipated benefit.

\subsubsection{Information on Programme Content influence on Gender Participation in BALDP}

The study also assessed the influence of access to information on BALDP content. This analysis was informed by the premise that awareness of the content of the BALDP will enable community members to judge the value of the programme to the personal and professional life. The aim of the analysis was to establish whether there is differential access to information regarding BALDP content by men and women, which could explain gender disparities in BALDP participation. Respondents were asked to give their views of several statements relating to this issue. Their responses are summarized in Table 12.

Table 12: Access to Information on BALDP Content by Males and Females

\begin{tabular}{|c|c|c|c|c|c|c|c|}
\hline \multicolumn{8}{|c|}{ Key: $1=$ strongly disagree, $2=$ disagree, $3=$ undecided, $4=$ agree, and $5=$ strongly agree } \\
\hline \multirow[t]{2}{*}{ Statement } & \multirow[t]{2}{*}{ Gender } & 1 & 2 & 3 & 4 & 5 & \multirow{2}{*}{$\begin{array}{l}X^{2} \text { Test } p- \\
\text { value }\end{array}$} \\
\hline & & $\%$ & $\%$ & $\%$ & $\%$ & $\%$ & \\
\hline \multirow{2}{*}{$\begin{array}{l}\text { I understand the learning outcomes that I am } \\
\text { expected to achieve at the end of the programme }\end{array}$} & Male & 9.4 & 1.9 & 0.0 & 26.4 & 62.3 & \multirow{2}{*}{0.079} \\
\hline & Female & 1.3 & 3.8 & 5.1 & 33.3 & 56.4 & \\
\hline \multirow{2}{*}{$\begin{array}{l}\text { I am fully aware of the subjects that I am } \\
\text { supposed to study in this programme }\end{array}$} & Male & 13.2 & 3.8 & 3.7 & 32.1 & 47.2 & \multirow{2}{*}{$0.032 *$} \\
\hline & Female & 1.3 & 1.3 & 2.6 & 28.2 & 66.7 & \\
\hline \multirow{2}{*}{$\begin{array}{l}\text { I understand the skills and knowledge that I am } \\
\text { expected to acquire at the end of the programme }\end{array}$} & Male & 5.7 & 0.0 & 1.9 & 39.6 & 52.8 & \multirow{2}{*}{0.270} \\
\hline & Female & 1.3 & 2.6 & 0.0 & 46.2 & 50.0 & \\
\hline \multirow{2}{*}{$\begin{array}{l}\text { I am aware of my responsibilities as student in the } \\
\text { adult learning process. }\end{array}$} & Male & 5.7 & 3.8 & 1.9 & 24.5 & 64.2 & \multirow{2}{*}{0.111} \\
\hline & Female & 2.6 & 0.0 & 5.1 & 39.7 & 52.6 & \\
\hline \multirow{2}{*}{$\begin{array}{l}\text { I am aware of the materials that I require in order } \\
\text { to fulfil the learning outcomes of my programme }\end{array}$} & Male & 3.8 & 3.8 & 1.9 & 30.2 & 60.4 & \multirow{2}{*}{0.915} \\
\hline & Female & 1.3 & 3.8 & 1.3 & 30.8 & 62.8 & \\
\hline
\end{tabular}

\section{*Significant at 0.05 level}

Source: Field Data (2020)

Results in Table 12 show that more female respondents $(89.7 \%)$ than males $(88.7 \%)$ reported that they understand the learning outcomes that they are expected to achieve at the end of the programme. The chi-square test, however, showed that the difference in the proportion of males and females who agreed with the statement was not statistically significant $(\mathrm{p}=0.079)$. This 
International Journal of Social Science and Economic Research

ISSN: 2455-8834

Volume:06, Issue:07 "July 2021"

implies that males and females had more or less similar level of understanding of BALDP learning outcomes and thus this factor cannot explain where there is low participation in BALDP by men.

Similarly, more female respondents (94.9\%) than male respondents (79.3\%) affirmed that they were fully aware of the subjects that they are supposed to study in the BALDP. This time, the chi-square test showed that the difference between the proportion of males and females who agreed with the statement was statistically significant $(\mathrm{p}=0.032)$. These findings imply that female learners have significantly better understanding of the subjects that make up the B ALDP as compared to male learners. This phenomenon may explain why there is higher participation in the BALDP among females than males. It is probable that heightened awareness of the subjects makes women more prepared for the programme and shapes their expectations and involvement in the programme.

The findings show that there was no significant difference in males and females: understanding of the skills and knowledge that they are expected to acquire at the end of the programme $(\mathrm{p}=0.270)$, awareness of their responsibilities as students in the adult learning process $(\mathrm{p}=0.11)$, and awareness of the materials that they require in order to fulfil the learning outcomes of the BALDP. These findings imply that males and females have more or less similar access to information on these issues and thus access to this information cannot explain gender disparities in BALDP participation in Nakuru West Sub-County.

\section{CONCLUSIONS AND RECOMMENDATIONS}

Based on the findings, the study concludes that participation in BALDP in Nakuru West is greater among females than males. Women have high enrolment rate, class attendance, class involvement and programme completion rate. Limited access to information regarding the subjects that comprise the BALDP influences the low participation by men in the programme. Findings showed that fewer men than women have adequate understanding of the subjects that make up the BALDP. In addition, the capacity of the programme to deliver the benefit that males anticipate from the programme could also explain their low level of participation in BALDP.

To address limited access to information regarding the subjects that make up the BALDP among men, instructors should ensure that this information is disseminated to all students during the programme orientation session. The directorate of adult education in Nakuru West should also prepare materials that document all essential details about the programme including its outcomes, benefits, content and the units to be covered. This information should be presented in simple terms so as to address the literacy level of most learners. 


\section{International Journal of Social Science and Economic Research}

ISSN: $2455-8834$

Volume:06, Issue:07 "July 2021"

There is also a need to tailor-make the BALDP with the needs and anticipation of all learners including male learners. The findings revealed that men anticipated slightly different benefits from the BALDP when compared to females. Instructors should conduct an inquiry at the beginning of every course to understand what each learner intends to gain from the programme and then tailor the content and activities in line with the goal of each learner.

The present study was confined to Nakuru West Sub-County. To promote generalization of these findings, future studies should consider replicating this study in other sub-counties. The study examined the influence of three factors on gender participation in BALDP namely socio-cultural factors, household economic factors and access to programme information. These factors do not by any means provide a comprehensive explanation of the gender disparities that characterize the BALDP in Kenya. Future studies should explore the influence of different set of factors such as the infrastructure in the learning centres, social integration within the centres, labour market factors, religious beliefs and psychological elements such as learners' academic self-concept.

\section{REFERENCES}

Blunch, N. (2017). Adult literacy programs in developing countries. IZA World of Labor. doi: 10.15185/izawol.374.

Bryman, A. (2016). Social Research Method (5 $5^{\text {th }}$ ed.). London, UK: Oxford University Press.

Chadha, N., \& Wadhwa, S. (2018). Impact of an adult literacy programme on the personal and public lives of women: Evidence from India. Journal of South Asian Development, 13(1), $82-111$.

Chetty, K., Qigui, L., Gcora, N., Josie, J., Wenwei, L., \& Fang, C. (2018). Bridging the digital divide: Measuring digital literacy. Economics: Open-Assessment E-Journal, 12(23), 1-20.

County Government of Nakuru (2018). County Health Infrastructure Report. Nairobi: Government Printer.

Ebner, G., Bendix, T., \& Jager, T. (2018). Awareness raising for adult learning and education. Vienna, AU: European Association for the Education of Adults.

Fincham, J. (2018). Response rates and responsiveness for surveys, standards, and the journal. American Journal of Pharmaceutical Education, 72(2), 43- 51.

Kenya National Bureau of Statistics (2007). Kenya-2006 Kenya National Adults Literacy Survey. Nairobi: Government Printer. 


\section{International Journal of Social Science and Economic Research}

ISSN: $2455-8834$

Volume:06, Issue:07 "July 2021"

Kenya National Bureau of Statistics (2013). Exploring Kenya's inequality: Pulling apart or pooling together? Nairobi: Government Printer.

Korpershoek, H. \& King, R. (2019). Gender and cultural differences in school motivation. Research Papers in Education, 23(2), 131-151.

Lauglo, J. (2010). Engaging with adults: The case for increase support to adult basic education. New York: The World Bank Publishing.

Maguire, M., \& Delahunt, B. (2017). Doing a thematic analysis: A practical, step-by-step guide for learning and teaching scholars. Ireland Journal of Teaching and Learning in Higher Education, 8(3), 3351- 33514.

Mogeni, H. (2012). Factors influencing gender parity in adult basic education programmes in Masaba North District, Kenya (Unpublished thesis). University of Nairobi, Kenya.

Mohajan, H. (2017). Two criteria for good measurement in research: Validity and reliability.Annals of Spiru Haret University, 17(4), 56-82.

Ndegwa, A. (2016). Access and effective participation of adult basic education programmes in Nakuru North Sub-County, Nakuru County, Kenya (Unpublished thesis). Kenyatta University.

Ndiku, J., Muthamia, H., Ipara, O. \& Obaki, S. (2009). Adult education learners' recruitment: Challenges and prospects for re-engineered access to education in Kenya. Educational Research and Review, 4(7), 345- 353.

Pinder, R. (2011). Adult learners' understandings and expectations of literacy and their impact on participation in adult literacy programs (Unpublished thesis). The University of Michigan, U.S.

Read Educational Trust (2017). Benefits of literacy. Retrieved on June 5, 2019 from http://www.read.org.za/useful-info/benefits-of-literacy/.

Republic of Kenya (2010). National Adult and Continuing Education Policy. Nariobi: Government Printer.

Republic of Kenya (2012). A Policy Framework for Education: Aligning Education and Training to the Constitution of Kenya (2010) and the Kenya Vision 2030 and Beyond. Nairobi: Government Printer. 
International Journal of Social Science and Economic Research

ISSN: 2455-8834

Volume:06, Issue:07 "July 2021"

Sanda, A. (2014). Comparative analysis of male and female participation in adult basic literacy programme in Borno State. International Journal of Education and Research, 2(8), 393402.

Stromquist, N. (2016). Adult literacy and women: A present account. Dialogues in Social Justice, 1(1), 18-22.

UNESCO (2010). Global report on adult learning and education. Paris: UNESCO Publishing.

UNESCO (2016). Community-based adult learning and development programme, Philippines. Paris: UNESCO Publishing.

UNESCO (2017). Gender disparities in participation and completion vary by country group and education level. Paris: UNESCO Publishing.

UNESCO (2018). NaDEET Environmental literacy projects, Namibia. Paris: UNESCO Publishing.

Wanja, M. (2012). Determinant of gender disparities in adult literacy classes in Kenya: A case study of Magumoni Division, Meru-South District (Unpublished thesis). University of Nairobi, Kenya.

Windisch, H. (2015). Adults with low literacy and numeracy skills: A literature review on policy intervention. Paris: OECD Publishing. 